\title{
An Empirical Study on Usability of Online Hotel Reservation Websites
}

\author{
Kritsada Sriphaew and Pornphimon Katkaeo
}

\begin{abstract}
With the popularity of the websites, online business can generate more benefit and possibly be success rapidly. One key success factor is the usability of the websites. Three quality characteristic factors based on usability are investigated, i.e., user experience, functionality and user interface usability. User experience concerns with aesthetic attributes, functionality checks for the appropriate functions, and user interface usability focuses on a good UI design or easy-to-use website. Furthermore, an approach to measure usability including measuring metrics is proposed to assess the tasks related to online hotel reservation. Searching hotel, displaying search result, displaying room detail, and making a reservation tasks are evaluated their usability scores with fiverating Likert scale by the sample group of users. The empirical result shows that the rating score conforms to the rank and reflects the performance in use of the website. Booking.com has highest rating score of 4.11 while Hotels.com and Agoda.com have equal rating score of 4.09. Combining the best parts of each website can produce the website with higher rating score of 4.20 .
\end{abstract}

Index Terms-Usability, hotel reservation, user experience (UX), functionality, user interface (UI).

\section{INTRODUCTION}

The current trend in which e-commerce business must take into consideration is its website quality based on customer satisfaction and experience among competitors [1]. This is the key success factor for the benefit of business especially the online hotel reservation [2]. According to the access statistic of similar websites (www.similarweb.com), there are some differences between the ranks of online hotel reservation websites although they perform the same tasks and sell the same products. Highest Rank means highest number of users and average users' time spent on the website. The key factor is the usability of the website. Consider the online hotel reservation websites, four basic functions are hotel search, hotel and room type selection, price checking and making a reservation. Although these four basic functions are similar and exist among competitor websites, there are some differences among them such as pattern, content, easiness and difficulty of usage and the experience of user in using them. As stated in [3], aesthetic of the website is considerably factor to the website access statistics. Moreover, the usability and content of the website are also the important factors for users to choose those websites. Design features are another factor that had been studied in [4]. It was found that several design features do

Manuscript received February 1, 2017; revised April 1, 2017.

Kritsada Sriphaew and Pornphimon Katkaeo are with College of Information and Communication Technology, Rangsit University, Pathum Thani, Thailand (e-mail: kritsada@rsu.ac.th, pornphimon.kw@gmail.com). not entirely conform to the usability standard and design principles in which it results to making more difficulty for user experience. Furthermore, the number of links on the website, architectural design, graphic, and font are also affected to the usability [5].

In order to study the usability factors that effect websites' popularity, top three websites (as shown during late 2015 in www.similarweb.com) in travel category with accommodation and hotel subcategory are taken into consideration, i.e., Booking.com, Hotels.com, and Agoda.com. Note that Airbnb.com is excluded since its products are specific and different from other websites. Completing online hotel reservation task, detailed study on user experiences is investigated on those three prominent websites. With the assumption that a combination of good user experience parts from different websites may effect to the higher score of user experience, we then develop a new website constructed by the parts of websites with the highest scores of user experiences, and investigate by user assessment.

\section{USABILITY AND USER EXPERIENCE}

Bevan [6] proposed several factors that can be used to measure the usability and UX of the system as in Table I. Usability is variously interpreted as good user interface (UI), easy-to-use system, good user performance and satisfaction. User experience (UX) is basically defined as a constant "good" or "bad" feeling towards any product or service to finish a task [7]. UX is constituted of several elements [8], and can be related to different interpretations [9], i.e., 1) UX attributes, 2) UX goals, actual UX, and UX consequences.

There are two approaches to evaluate the UX of the website [10]: 1) observation of users' errors when navigating websites, and 2) expert style heuristic.

\section{USABILITY AND USER EXPERIENCE}

To assess the usability of online hotel reservation websites, a heuristic evaluation has been used. In this section, the design of measuring metrics is introduced and the methodology to measure the usability is proposed.

\section{A. Designing Methodology}

The methodology to solve this research problem is to conduct an empirical study by dividing the investigation into two steps as follows.

First step: Users were asked to access these three websites, i.e., Booking.com, Hotels.com, and Agoda.com, by performing following four main tasks: searching hotel (Task 1), displaying search result (Task 2), displaying room detail (Task 3), and making a reservation (Task 4). Later, the users 
were asked to give the scores for each measuring issues (explained later in Section 3.2) of each website.

TABLE I: FACTORS CONTRIBUTING TO SYSTEM USABILITY AND UX [6]

\begin{tabular}{|c|c|c|c|c|c|c|}
\hline $\begin{array}{l}\text { Quality } \\
\text { characteristic }\end{array}$ & UX & Functionality & $\begin{array}{l}\text { User interface (UI) } \\
\text { usability }\end{array}$ & Learnability & Accessibility & Safety \\
\hline Product attributes & $\begin{array}{l}\text { Aesthetic } \\
\text { attributes }\end{array}$ & $\begin{array}{l}\text { Appropriate } \\
\text { functions }\end{array}$ & $\begin{array}{l}\text { Good UI design } \\
\text { (easy to use) }\end{array}$ & $\begin{array}{l}\text { Learnability } \\
\text { attributes }\end{array}$ & $\begin{array}{c}\text { Technical } \\
\text { accessibility }\end{array}$ & $\begin{array}{l}\text { Safe and secure } \\
\text { design }\end{array}$ \\
\hline $\begin{array}{l}\text { UX pragmatic do } \\
\text { goals }\end{array}$ & \multicolumn{6}{|c|}{ To be effective and efficient } \\
\hline $\begin{array}{l}\text { UX hedonic be } \\
\text { goals }\end{array}$ & \multicolumn{6}{|c|}{ Stimulation, identification and evocation } \\
\hline $\begin{array}{r}\text { UX actual } \\
\text { experience }\end{array}$ & Visceral & \multicolumn{5}{|c|}{ Experience of interaction } \\
\hline $\begin{array}{c}\text { Usability } \\
\text { (=performance in } \\
\text { use measures) }\end{array}$ & \multicolumn{3}{|c|}{$\begin{array}{l}\text { Effectiveness and Productivity in use: effective task } \\
\text { completion and efficient use of time }\end{array}$} & $\begin{array}{l}\text { Learnability in } \\
\text { use: effective } \\
\text { and efficient to } \\
\text { learn }\end{array}$ & $\begin{array}{l}\text { Accessibility in } \\
\text { use: effective and } \\
\text { efficient with } \\
\text { disabilities }\end{array}$ & $\begin{array}{l}\text { Safety in use: } \\
\text { occurrence of } \\
\text { unintended } \\
\text { consequences }\end{array}$ \\
\hline \multirow{2}{*}{$\begin{array}{c}\text { Measures of } \\
\text { UX consequences }\end{array}$} & \multicolumn{6}{|c|}{$\begin{array}{l}\text { Satisfaction in use: } \\
\text { satisfaction with achieving pragmatic and hedonic goals }\end{array}$} \\
\hline & Pleasure & \multicolumn{4}{|c|}{ Liability and Comfort } & Trust \\
\hline
\end{tabular}

Second step: After computing usability scores in the first step, we will receive the best practices of each task from different websites. Theses best practices are selected to develop a new website with those best practices which is a synergy from different online hotel reservation websites. Similar to the first step, the same group of users was asked to use the website and give the scores without given any clue information.

The objective of the first step is to asses the usability of each task for those three websites and in total while the objective of the second step is to prove the hypothesis that the new website developed from a combination of the best practices (highest scores of usability) of each task provides higher score of usability or not.

\section{B. Designing Measuring Metrics}

To design metrics for measuring the usability, the most common and possible way is to create the questionnaires with regard to each quality characteristic that we want to investigate [3]. According to quality characteristics mentioned in Section II, three constituents of usability must be investigated. UX concerns with aesthetic attributes, functionality checks for the appropriate functions, and UI usability focuses on a good UI design or easy-to-use website. Using the five-rating Likert scale, the aspect and the meaning of scale used for assessing UX, functionality and UI usability in this work are shown in Table II.

TABLE II: MEANING OF FIVE-RATING LIKERT SCALE FOR QUALITY

\begin{tabular}{|c|c|c|c|c|c|}
\hline $\begin{array}{c}\text { Quality } \\
\text { Characteristic } \\
\text { (Aspect for } \\
\text { Evaluation) }\end{array}$ & 1 & 2 & 3 & 4 & 5 \\
\cline { 2 - 6 } & \multicolumn{5}{|c|}{ Meaning of 5-rating Likert Scale } \\
\hline $\begin{array}{c}\text { UX } \\
\text { (Aesthetic) }\end{array}$ & Worst & Poor & Mid & Good & Best \\
\hline $\begin{array}{c}\text { Functionality } \\
\text { (Completeness } \\
\text { of Content) }\end{array}$ & $\begin{array}{c}\text { No } \\
\text { content }\end{array}$ & $\begin{array}{c}\text { Not } \\
\text { Complete }\end{array}$ & Mid & $\begin{array}{c}\text { Comple } \\
\text { te }\end{array}$ & $\begin{array}{c}\text { Very } \\
\text { Com } \\
\text { plete }\end{array}$ \\
\hline $\begin{array}{c}\text { UI usability } \\
\text { (Easiness and } \\
\text { Difficulty) }\end{array}$ & $\begin{array}{c}\text { Very } \\
\text { Difficult }\end{array}$ & Difficult & Mid & Easy & $\begin{array}{c}\text { Very } \\
\text { Easy }\end{array}$ \\
\hline
\end{tabular}

As coherent with ISO/IEC CD 25010.2 [11], the questions used for measuring quality characteristics, which are usability factors, of online hotel reservation websites are proposed as in Table III.

TABLE III: QUESTIONS FOR MEASURING USABILITY FACTORS OF ONLINE HOTEL RESERVATION WEBSITES

\begin{tabular}{|c|c|c|c|}
\hline \multirow{2}{*}{ Task } & \multicolumn{3}{|c|}{ Questions for Measuring Quality Characteristics } \\
\hline & $\mathbf{U X}$ & Functionality & UI Usability \\
\hline $\begin{array}{c}\text { Task 1: } \\
\text { Searching Hotel }\end{array}$ & $\begin{array}{l}\text { - pattern of search box } \\
\text { - pattern of calendar } \\
\text { - pattern of selecting } \\
\text { number of nights to stay } \\
\text { - pattern of selecting } \\
\text { number of guests } \\
\text { - font color } \\
\text { - background color } \\
\text { - button style }\end{array}$ & - completeness of criteria for searching & $\begin{array}{l}\text { - easily to select province name } \\
\text { by typing } \\
\text { - easily to select check-in date by } \\
\text { typing } \\
\text { - easily to select check-in date by } \\
\text { provided calendar } \\
\text { - easily to select number of nights } \\
\text { to stay } \\
\text { - easily to select number of } \\
\text { guests } \\
\text { - easily to end task by pressing } \\
\text { Enter button on the keyboard } \\
\text { - end task by clicking on search } \\
\text { button }\end{array}$ \\
\hline $\begin{array}{c}\text { Task 2: } \\
\text { Displaying } \\
\text { Search Result }\end{array}$ & $\begin{array}{l}\text { - arrangement of results } \\
\text { - font color and style } \\
\text { - pattern to display pictures }\end{array}$ & $\begin{array}{l}\text { - } \text { completeness of room detail } \\
\text { - completeness of facility detail } \\
\text { - completeness of expense detail } \\
\text { - completeness in showing room picture }\end{array}$ & $\begin{array}{l}\text { - organize pattern for easy-to- } \\
\text { read arrangement }\end{array}$ \\
\hline
\end{tabular}




\begin{tabular}{|c|c|c|c|}
\hline $\begin{array}{c}\text { Task 3: } \\
\text { Displaying Room } \\
\text { Detail }\end{array}$ & $\begin{array}{l}\text { - arrangement of results } \\
\text { - font color and style } \\
\text { - pattern to display pictures }\end{array}$ & $\begin{array}{l}\text { - completeness in displaying room detail } \\
\text { - completeness in providing gadget in displaying } \\
\text { detail } \\
\text { - additional functions: e.g., zoom-in/out when mouse } \\
\text { over } \\
\text { - gadget in displaying provided detail }\end{array}$ & $\begin{array}{l}\text { - easily to select view other detail } \\
\text { - show room picture in obvious } \\
\text { position } \\
\text { - show expense detail in obvious } \\
\text { position }\end{array}$ \\
\hline $\begin{array}{l}\text { Task 4: } \\
\text { Making a } \\
\text { Reservation }\end{array}$ & $\begin{array}{l}\text { - arrangement of results } \\
\text { - font color and style } \\
\text { - pattern to display pictures }\end{array}$ & $\begin{array}{l}\text { - completeness of information on filling out personal } \\
\text { detail } \\
\text { - completeness of information on filling out payment } \\
\text { detail } \\
\text { - clear and understandable of expense detail } \\
\text { - completeness of payment detail } \\
\text { - feel safe of payment detail }\end{array}$ & $\begin{array}{l}\text { - easily to fill in user detail } \\
\text { - easily to fill in payment detail }\end{array}$ \\
\hline
\end{tabular}

\section{EMPIRICAL RESULTS}

For the best ranking of websites in travel/accommodation category, total number of visits is 269.4 millions $^{1}$ with 7:54 seconds time spent on site. Assume that the number of visits is a factor of the number of users, with $15 \%$ margin of error and $95 \%$ confidence level, the sample size is 43 users. Therefore, the experiments were conducted on 43 users who have some experiences in online hotel reservation. The results are shown in Table IV.

TABLE IV: EMPIRICAL RESULTS

\begin{tabular}{ccccc}
\hline \hline $\begin{array}{c}\text { Quality } \\
\text { Charac } \\
\text { teristic }\end{array}$ & Task & $\begin{array}{c}\text { Booking. } \\
\text { com }\end{array}$ & $\begin{array}{c}\text { Hotels. } \\
\text { com }\end{array}$ & $\begin{array}{c}\text { Agoda. } \\
\text { com }\end{array}$ \\
\cline { 3 - 5 } & & 4.09 & 4.11 & 4.13 \\
UX & 1 & 4.18 & 4.13 & 4.11 \\
& 2 & 4.14 & 4.10 & 4.07 \\
& 3 & 4.13 & 4.13 & 4.13 \\
Functio & 4 & 4.11 & 4.07 & 3.96 \\
nality & 1 & 4.05 & 3.96 & 4.10 \\
& 3 & 4.02 & 4.11 & 4.11 \\
\hline UI & 4 & 3.94 & 3.99 & 4.18 \\
\hline Usabilit & 1 & 4.07 & 4.03 & 4.03 \\
y & 2 & 4.16 & 4.23 & 4.03 \\
\hline \hline Average & 3 & 4.25 & 4.18 & 3.99 \\
\hline \hline
\end{tabular}

From Table IV, Booking.com provides highest average score that outperforms Hotels.com and Agoda.com, respectively, which conforms to the ranks in www.similar.com. Furthermore, user spent highest time on Booking.com too. This means that the factors that were studying in this research are somewhat related to the popularity of the websites. By averaging the rating score grouped by task, the best practice websites for each task are summarized in Table V.
TABLE V: AVERAGING RATING SCORE GROUPED BY TASK OF INVESTIGATED AND NEWLY-DEVELOPED WEBSITES

\begin{tabular}{cccc||c}
\hline \hline & \multicolumn{3}{c}{ Average Rating Score } \\
\cline { 2 - 5 } Task & $\begin{array}{c}\text { Booking } \\
\text {.com }\end{array}$ & $\begin{array}{c}\text { Hotels. } \\
\text { com }\end{array}$ & $\begin{array}{c}\text { Agoda } \\
\text {.com }\end{array}$ & $\begin{array}{c}\text { Newly- } \\
\text { Developed } \\
\text { Website }\end{array}$ \\
\hline Task 1 & 4.09 & 4.07 & 4.04 & 4.03 \\
Task 2 & 4.13 & 4.11 & 4.08 & 4.19 \\
Task 3 & 4.14 & 4.13 & 4.06 & 4.57 \\
Task 4 & 4.07 & 4.05 & 4.18 & 4.00 \\
\hline \hline Average & 4.11 & 4.09 & 4.09 & 4.20 \\
\hline \hline
\end{tabular}

With the detailed investigation on the questions (referred to Table III) asked during measuring usability factors, we analyze all characteristics to find out the best practices, e.g., pattern of search box, font color and style, completeness of search result, ease of the menu, arrangement of the items in the website, etc. We then develop the new website with those best practices and repeat second step by asking sample group to give rating scores for measuring usability factors of each task. The results are shown in the last column of Table $\mathrm{V}$. It reflects that the rating score is dramatically improved to be 4.20 although the average rating scores of some tasks become lower than those three investigated websites.

\section{CONCLUSION}

This paper studied the usability factors that effect website's popularity by the investigation on top three online hotel reservation websites, i.e., Booking.com, Hotels.com, and Agoda.com. The work focuses on the performance in use measures of the websites where three factors are concerned. UX concerns with aesthetic attributes, functionality checks for the appropriate functions, and UI usability focuses on a good UI design or easy-to-use website. Designing methodology and measuring metrics were proposed to assess the quality characteristics of the websites. The rating scores of investigated factors conform to the ranking of websites. With the combination of the best practices in each website, a new website had been developed and assessed. The average rating score showed that newlydeveloped website can increase the total rating score. 


\section{ACKNOWLEDGMENT}

The authors wish to thank Research Institute of Rangsit University for the grant support.

\section{REFERENCES}

[1] C. Wang, Z. Mao, J. Johansen, J. T. Luxhøj, J. O'Kane, J. Wang et al, "Critical success criteria for B2B e-commerce systems in chinese medical supply chain," International Journal of Logistics Research and Applications, vol. 19, no. 2, pp. 105-124, Apr. 2015.

[2] J. N. K. Liu and E.Y. Zhang, "An investigation of factors affecting customer selection of online hotel booking channels," International Journal of Hospitality Management, vol. 39, pp. 71-83, May 2014.

[3] A. Bartuskova and O. Krejcar, "Evaluation framework for user preference research implemented as web application," in Proc. 2013 5th International Conference on Computational Collective Intelligence, Technologies and Applications, vol. 8083, pp. 537-548.

[4] H. Idyamwati, M. Mahmud, and A. O. M. Tap, "User experience: Assessing the effectiveness of internet booking service," in Proc. 2010 International Conference on User Science and Engineering, pp. $1-6$.

[5] T. Treeratanapon, "The influence of design dimensions on website usability: an empirical study," unpublished Ph.D. dissertation, King Mongkut's University of Technology Thonburi, Thailand, 2010.

[6] N. Bevan, "Classifying and selecting UX and usability measures," in Proc. 5th COST294-MAUSE Open Workshop on Meaningful Measures: Valid Useful User Experience Measurement (VUUM), 2008.

[7] ISO DIS 9241-210: 2008, "Ergonomics of human system interaction - Part 210: Human-centered design for interactive systems (formerly known as 13407)," International Standardization Organization (ISO), 2008.

[8] J. J. Garrett. (March 3, 2016). The elements of user experience: Usercentered design for the web. New Riders Publishing. [Online]. Avalizble: http://www.jjg.net/elements/pdf/elements_ch02.pdf

[9] M. Hassenzahl and N. Tractinsky, "User experience - A research agenda," Behaviour \& Information Technology, vol. 25, no. 2, pp. 91-97, 2006
[10] A. G. Sutcliffe, "Scenario-based requirements analysis," Requirements Engineering Journal, vol. 3, no. 1, pp. 48-65, 1998.

[11] ISO/IEC CD 25010.2, "Software engineering - Software product quality requirements and evaluation (SQuaRE)," I.JTC1/SC7, 2008.

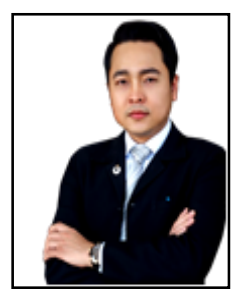

Kritsada Sriphaew was born in Bangkok, Thailand on March 3, 1980. He graduated B.Eng. in computer engineering (second class honors) from King Mongkut's Institute of Technology, Thailand in 2000 and graduated Ph.D. in information technology from Sirindhorn International Institute of Technology, Thammasat University, Thailand in 2007.

$\mathrm{He}$ worked as a teaching assistant in Sirindhorn International Institute of Technology during his study and continued to be adjuct lecturer at the institute since 2007 up until now. He was being a postdoctoral researcher in Okumura group of Precision and Intelligence Laboratory, Tokyo Institute Technology during 2007-2008 and JSPS postdoctoral fellow from Japan Society for the Promotion of Science, Ministry of Education, Culture, Sports, Science and Technology (MEXT) in Okumura group during 2008-2010. After returning to home country in 2010, he is currently working as full-time lecturer in Rangsit University since 2011. He received assistant professor position in 2015. His research areas are data mining, text mining, computational linguistics, social media analytics and human computer interaction.

Asst. Prof. Dr. Kritsada Sriphaew is a co-founder of the Artificial Intelligence Association of Thailand (AIAT) and a member of IACT.

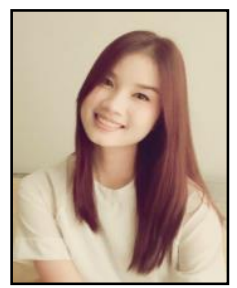

Pornphimon Katkaeo was born in Hatyai, Songkla on January 15, 1992. She graduated B.Sc. in information technology (first class honors) from Rangsit University, Thailand in 2011 and graduated M.Sc. in information technology from Rangsit University, Thailand in 2016.

She is currently working as consultant at I-MAS consulting (Thailand) Co., Ltd. since 2014. Her expert area is accounting information system and enterprise resource planning system. 